\title{
Reconstruction of paleotyphoons and recurrence of extreme floods in south Sakhalin Island in Middle-Late Holocene
}

\author{
Nadezhda G. Razjigaeva*1 \\ Tatiana A. Grebennikova ${ }^{1}$ \\ Larisa A. Ganzey ${ }^{1}$ \\ Alexey O. Gorbunov ${ }^{2}$ \\ Vladimir I. Ponomarev ${ }^{3}$ \\ Mikhail A. Klimin ${ }^{4}$ \\ Khikmatulla A. Arslanov 5 \\ Fedor E. Maksimov ${ }^{5}$ \\ Alexey Yu. Petrov ${ }^{5}$
}

\author{
${ }^{1}$ Pacific Geographical Institute, FEB RAS, Vladivostok, Russia \\ ${ }^{2}$ Institute of Marine Geology and Geophysics, FEB RAS, \\ Yuzhno-Sakhalinsk, Russia \\ ${ }^{3}$ V.I. Il 'ichev Pacific Oceanological Institute, FEB RAS, Vladivostok, \\ Russia \\ ${ }^{4}$ Institute of Water and Ecological Problems, FEB RAS, Khabarovsk, \\ Russia \\ ${ }^{5}$ St.-Petersburg State University, St.-Petersburg, Russia \\ *E-mail:nadyar@tigdvo.ru
}

\begin{abstract}
Peзюмe Rus PDF
The geological record of extreme floods associated with the passage of the strongest typhoons in the last 6620 cal. yr. was first restored for the Sakhalin Island. The cross-section of the Holocene deposits near Dolinsk Town (the watershed in the northern part of the Susunai lowland) was chosen as a natural archive for paleotyphoon activity. The cross-section includes the peat bog with numerous loam layers which formed during the flooding of the swamp during extreme floods. The results of the ecological and taxonomic composition of diatom flora study have been presented with the aim of restoring the evolution of sedimentation environments, as well the analysis of the moisture dynamics and river activity. Peat bog has been formed on the place of the lagoon existed in the maximum phase of transgression in the Middle Holocene. Peat accumulation has begun 6010 cal. yr. BP in brackish-water lagoon. The lagoon had turned into the coastal lake when sea level dropped 5710-5040 cal. yr. BP. Some bioindicators were revealed for identification of severe floods. One of the criteria for identifying the periods of frequent floods is the analysis of the ash content of peat. The age of 25 extreme floods was determined and the paleoclimatic background of events was analyzed. The catastrophic flood caused by Phyllis typhoon (1981) has been considered as an analogue of paleo-events. It is established that the repeatability of extreme typhoons increased in both warm wet and dry and cold dry phases, three periods of their activation were identified (4640-4360; 4030-3580; 1860-1380 cal. yr. BP), when super typhoons entered the island once in 30-90 years. The manifestations of extreme typhoons in south Sakhalin and in the Sea of Japan region have been compared. The super typhoon tracks seemed to be changed in a radical manner during paleo times as well in the period of the instrumental meteorological observations.
\end{abstract}

\section{Keywords}

extreme floods, paleotyphoons, geological criteria, diatoms, chronology, recurrence, Middle-Late Holocene, Sakhalin Island

For citation: Razjigaeva N.G., Grebennikova T.A., Ganzey L.A., Gorbunov A.O., Ponomarev V.I., Klimin M.A., Arslanov Kh.A., Maksimov F.E., Petrov A.Yu. Reconstruction of paleotayphoons and recurrence of extreme floods in south Sakhalin Island in Middle-Late Holocene. Geosystems of Transition Zones, 2020, vol. 4, no. 1, p. 46-70. (In Russian). https://doi.org/10.30730/2541-8912.2020.4.1.046-070 
Для цитирования: Разжигаева Н.Г., Гребенникова Т.А., Ганзей Л.А., Горбунов А.О., Пономарев В.И., Климин М.А., Арсланов Х.А., Максимов Ф.Е., Петров А.Ю. Реконструкция палеотайфунов и повторяемости экстремальных паводков на юге острова Сахалин в среднем-позднем голоцене.

Геосистемы переходных зон. 2020. Т. 4, № 1. С. 46-70. https://doi.org/10.30730/2541-

8912.2020.4.1.046-070

\section{References}

1. Akiba F., Hiramatsu Ch., Tsoy I.B., Ogasawara K., Amano K. 2000. Diatom biostratigraphy and geologic age of the Maruyama and Kurasi Formations, Southern Sakhalin, and their correlation to the Neogene of the Tenpoku Area, Hokkaido. J. of Geography (Chigaku Zasshi), 109(2): 203-217. https://doi.org/10.5026/jgeography.109.2_203

2. Astakhov A.S., Aksentov K.I., Dar'in A.V., Kalugin I.A. 2019. Reconstructing the Frequency of Catastrophic Floods on the Western Coast of the Sea of Japan Based on Sedimentary Proxy. Russian Meteorology and Hydrology, 44(1): 62-70. https://doi.org/10.3103/s1068373919010072

3. Barinova S.S., Medvedeva L.A., Anisimova O.V. 2006. Bioraznoobrazie vodoroslei-indikatorov okruzhaiushchei sredy [Biodiversity of algae - the environment indicators]. Tel'-Aviv: Pilies Studio, $498 \mathrm{p}$.

4. Bazarova V.B., Klimin M.A., Kopoteva T.A. 2018. Holocene dynamics of the East-Asian monsoon in the Lower Amur area. Geography and Natural Resources, 39(3): 239-247. https://doi.org/10.1134/s1875372818030071

5. Blaauw M., Christen J.A. 2011. Flexible paleoclimate age-depth models using an 601 autoregressive gamma process. Bayesian Analysis, 6(3): 457-474. doi.org/10.1214/11-ba618

6. Bond G., Kromer B., Beer J., Muscheler R., Evans M.N., Showers W., Hoffmann S., Lotti-Bond R., Hajdas I., Bonani G. 2001. Persistent solar influence on North Atlantic climate during the Holocene. Science, 294: 21302136. doi.org/10.1126/science. 1065680

7. Bronk Ramsey C. 2017. Methods for summarizing radiocarbon datasets. Radiocarbon, 59(2): 1809-1833. doi.org/10.1017/rdc.2017.108

8. Byshev V.I., Neiman V.G., Romanov Y.A., Serykh I.V., Ponomarev V.I., Tsurikova T.V. 2014. The influence of global atmospheric oscillation on formation of climate anomalies in the Russian Far East. Doklady Earth Sciences, 458(1): 1116-1120. https://doi.org/10.1134/s1028334x14090025

9. Chen R., Shen J., Li C., Zhang E., Sun W., Ji M. 2015. Mid- to Late-Holocene East Asian summer monsoon variability recorded in lacustrine sediments from Jingpo Lake, Northeastern China. The Holocene, 25: 454468. doi.org/10.1177/0959683614561888

10. Cherepanova M.V. 1988. [The Diatoms as indicators of conditions of sediments accumulation in Far East lagoons]. In: Kolichestvennye parametry prirodnoi sredy v pleistotsene [Quantitative parameters of natural environment in the Pleistocene]. Vladivostok: DVO AN SSSR, 172-177.

11. Davydova I.N. 1985. Diatomovye vodorosli - indikatory prirodnykh uslovii vodoemov v golotsene [Diatoms the indicators of basins natural conditions in Holocene]. Leningrad: Nauka Publ., 244 p.

12. Diatomovyi analiz [Diatom analysis]. Book 3. 1950. Leningrad: Gosgeolitizdat, $632 \mathrm{p}$.

13. Elsner J.B., Liu K.B. 2003. Examining the ENSO-typhoon hypothesis. Climate Research, 25: 43-54. doi.org/10.3354/cr025043

14. Gartsman B.I., Mezentseva L.I., Menovshchikova T.S., Popova N.Y., Sokolov O.V. 2014. Conditions of generation of extremely high water content of Primorye rivers in autumn-winter 2012. Russian Meteorology and Hydrology, 39(4): 260-270. https://doi.org/10.3103/s1068373914040074

15. Gensiorovskii Iu.V. 2011. Ekzogennye geologicheskie protsessy i ikh vliianie na territorial'noe planirovanie gorodov (na primere o. Sakhalin) [Exogenous geological processes and their influence on territorial planning of cities (by the example of Sakhalin Island)]: [dissertation abstract of the Candidate of geological and mineralogical sciences]. Irkutsk: IZK SO RAN, 23 p. (In Russ.).

16. Gensiorovskii Iu.V., Kazakov N.A. 2015. [The conditions of extreme floods formation in the river basins of low mountain relief (by the example of Sakhalin Island)]. In: Geodinamicheskie protsessy i prirodnye katastrofy. Opyt Neftegorska: materialy. Vseros. konf. s mezhdunar. uchastiem [Geodynamics processes and natural disasters. Neftegorsk experience: materials of the All-Russian conference with international participation]. Yuzhno-Sakhalinsk: IMGiG DVO RAN, vol. 2: 302-305.

17. Grebennikova T.A. 2009. [The Bacillariophyta flora of diverse basins of the Central and Northern Kurils]. Botanicheskii zhurnal [Botanical Journal], 94(4): 526-537.

18. Grebennikova T.A. 2011. Diatom flora of lakes, ponds and streams of Kuril Islands. In: Diatoms: Ecology and Life Cycle. New York: Nova Publ., 93-124.

19. Gvozdeva I.G., Mikishin Iu.A. 2008. [Stratigraphy and paleogeography of Holocene of south-western Sakhalin]. Estestvennye i tekhnicheskie nauki [Natural and technical sciences], 3: 177-183.

20. Henderson-Sellers A., Zhang H., Berz G., Emanuel K., Gray W., Landsea C., Holland G., Lighthill J., Shieh S.L., Webster P., McGuffie K. 1998. Tropical cyclones and global climate change: a post-IPCC assessment. Bull. of the American Meteorological Society, 79: 19-38. doi.org/10.1175/1520- 
21. Katsuki K., Yang D.Y., Seto K., Yasuhara M., Takata H., Otsuka M., Nakanishi T., Yoon Y., Um I.K., Cheung R.C.W., Khim B.K., Kashima K. 2016. Factors controlling typhoons and storm rain on the Korean Peninsula during the Little Ice Age. J. Paleolimnology, 55: 35-48. doi.org/10.1007/s10933-015-9861-3

22. Kawahata H., Ohshima H., Shimada C., Oba T. 2003. Terrestrial-oceanic environmental change in the southern Okhotsk Sea during the Holocene. Quaternary International, 108: 67-76. doi.org/10.1016/s10406182(02)00195-7

23. Kazakov N.A., Gensiorovskii Iu.V. 2007. Vliianie vertikal'nogo gradienta osadkov na kharakteristiki gidrologicheskikh, lavinnykh i selevykh protsessov v nizkogor'e [Influence of vertical gradient of sediments on the characteristics of hydrogeological, avalanche and mudflow processes in low-mountain]. Geoekologiia. Inzhenernaia geologiia. Gidrogeologiia. Geokriologiia [Geoecology. Engineering ecology. Geocriology], (4): 342-347.

24. Kharitonov V.G. 2010. Konspekt flory diatomovykh vodoroslei (Bacillariophyceae) Severnogo Okhotomor'ia [Summary of the diatom flora (Bacillariophyceae) of the Northern coast of the Okhotsk Sea]. Magadan: SVNTs DVO RAN [NESC FEB RAS], 189 p.

25. Kondakova L.V., Pirogova O.S. 2014. [Soil algae and cyanobacteriae of the "Nurgush" national nature reserve]. Teoreticheskaia i prikladnaia ekologiia [Theoretical and applied ecology], (3): 94-101.

26. Korotkii A.M., Pushkar' V.S., Grebennikova T.A., Razzhigaeva N.G., Karaulova L.P., Mokhova L.M., Ganzei L.A., Cherepanova M.V., Bazarova V.B., Volkov V.G., Kovaliukh N.N. 1997. Morskie terrasy $i$ chetvertichnaia istoriia shel'fa Sakhalina [The marine terraces and history of quaternary shelf of Sakhalin]. Vladivostok: Dal'nauka, 194 p.

27. Krammer K. 1992. Pinnularia, eine Monographie der europoischen Taxa. Bibliotheca Diatomologica, 26,35 p.

28. Krammer K., Lange-Bertalot H. 1986. Bacillariophyceae. 1. Teil: Naviculaceae. Jena: Gustav Fischer Verlag, 876 p. (In: Ettl H., Gerloff J., Heynig H., Mollenhauer D. (eds) Süsswasserflora von Mitteleuropa; 2).

29. Krammer K., Lange-Bertalot H. 1991. Bacillariophyceae. 3. Teil: Centrales, Fragilariaceae, Eunotiaceae. Jena: Gustav Fischer Verlag, 576 p. (In: Ettl H., Gerloff J., Heynig H., Mollenhauer D. (eds) Süsswasserflora von Mitteleuropa; 2).

30. Leipe C., Nakagawa T., Gotanda K., Müller S., Tarasov P. 2015. Late Quaternary vegetation and climate dynamics at the northern limit of the East Asian summer monsoon and its regional and global-scale controls. Quaternary Science Reviews, 116: 57-17. doi.org/10.1016/j.quascirev.2015.03.012

31. Li C., Wu Ya., Hou X. 2011. Holocene vegetation and climate in Northeast China revealed from Jingbo Lake sediment. Quaternary International, 229: 67-73. doi.org/10.1016/j.quaint.2009.12.015

32. Lim J., Lee J-Y., Hong S.S., Kim J.-Y., Yi S., Nahm W-H. 2017. Holocene change in flooding frequency in South Korea and their linkage to centennial-to-millennial-scale El Nino-Southern Oscillation activity. Quaternary Research, 87: 37-48. doi.org/10.1017/qua.2016.8

33. Liu K.B., Fearn M.L. 2000. Reconstruction of prehistoric landfall frequencies of catastrophic hurricanes in Northwestern Florida from lake sediment records. Quaternary Research, 54: 238-245. doi.org/10.1006/qres.2000.2166

34. Liu K.B., Shen C., Louie K.S. 2001. A 1,000 year history of typhoon landfalls in Guangdong, Southern China, reconstructed from Chinese historical documentary records. Annals of the Association of American Geographers, 91(3): 453-464. doi.org/10.1111/0004-5608.00253

35. Liu Y., Wang Q., Fu C. 2011. Taxonomy and distribution of diatoms in the genus Eunotia from the Da'erbin Lake and Surrounding Bogs in the Great Xing' an Mountains, China. Nova Hedwigia, 92(1-2): 205-232. doi.org/10.1127/0029-5035/2011/0092-0205

36. Lobanov V.B., Danchenkov M.A., Luchin E.V., Mezentseva L.I., Ponomarev V.I., Sokolov O.V., Trusenkova O.O., Ustinova E.I., Ushakova R.N., Khen G.V. 2014. Dal'nevostochnye moria Rossii. In: Vtoroi otsenochnyi doklad Rosgidrometa ob izmeneniiakh klimata i ikh posledstviiakh na territorii Rossiiskoi Federatsii [FarEastern seas of Russia. Second evaluation report of the Roshydromet on the climate changes and their consequences on the Russian Federation territory]. Moscow: Rosgidromet, chapter 5.4: 684-743.

37. Mikishin Iu.A., Gvozdeva I.G. 1996. Razvitie prirody iugo-vostochnoi chasti ostrova Sakhalin v golotsene [Nature evolution of Sakhalin Island south-eastern part in Holocene]. Vladivostok: DVGU Publ., 130 p.

38. Mikishin Iu.A., Gvozdeva I.G. 2016. [Late subatlantic of South Sakhalin]. Uspekhi sovremennogo estestvoznaniia = Advances in Current Natural Sciences, (9): 137-142.

39. Mikishin Iu.A., Gvozdeva I.G. 2017. [Early subboreal of Sakhalin]. Vestnik SVKNII DVO RAN = Bulletin of the North-East Scientific Center of FEB RAS, (4): 25-38.

40. Mikishin Iu.A., Gvozdeva I.G. 2018. [Cooling traces on the south of Sakhalin in the late Glacial and Atlantic period of Holocene]. Uspekhi sovremennogo estestvoznaniia = Advances in Current Natural Sciences, (3): $107-116$.

41. Mogil'nikova T.A., Motyl'kova I.V. 2003. [Summer phytoplankton of the Piltun lagoon (northern-east Sakhalin)]. In: Chteniia pamiati V.Ia. Levanidova [Readings dedicated to the memory of V.IA. Levanidov]. Vladivostok: Dal'nauka, iss. 2: 295-304.

42. Moy C.M., Seitzer G.O., Rodbell D.T., Anderson D.M. 2002. Variability of El Nino/Southern oscillation activity at millennium timescales during the Holocene epoch. Nature, 420: 162-165.

doi.org/10.1038/nature01194 
43. Nauchno-prikladnoi spravochnik po klimatu. Seriia 3. Mnogoletnie dannye. Iss. 34. Sakhalinskaia oblast' [Scientific and applied reference book on the climate. Series 3. Long-term data. Iss. 34. Sakhalin Region]. 1990. Leningrad: Gidrometeoizdat, $351 \mathrm{p}$.

44. Nikulina T.N. 2005. [Diatoms (Bacillariophyta) of the south Sakhalin Island]. In: Rastitel'nyi i zhivotnyi mir ostrova Sakhalin (Materialy Mezhdunar. Sakhalinskogo proekta) [Flora and fauna of Sakhalin Island (The materials of International Sakhalin project)]. Vladivostok: Dal'nauka, part 2: 8-21.

45. Pokhil A.E. 2011. Taifuny Tikhogo okeana - "zhivye' samoorganizuiushchiesia, razvivaiushchiesia i vzaimodeistvuiushchie sistemy [The Pacific Ocean typhoons - "alive" self-organizing, evolutive and interacting systems]. Energiia: ekonomika, tekhnika, ekologiia [Energy: economics, technics, ecology], (11): 57-65.

46. Poliakova E.I. 1979. [The diatoms in recent sediments of the Chuckchee Sea coast and their paleogeographic meaning]. Izvestiya RAN. Seriya Geograficheskaya = Bulletin of the Russian academy of Science: Geographical Series, (4): 90-94.

47. Prushkovskaia I.A. 2019. [Typhoons influence on content of diatoms in the Amur bay (Japan Sea) sediments for the last 100 years]. Vestnik KRAUNTs. Nauki o Zemle = Bull. of Kamchatka Regional Association "Educational-Scientific Center". Earth Sciences, 2: 111-119. doi.org/10.31431/1816-5524-2019-2-42-111-119

48. Pushkar' V.S., Cherepanova M.V. 2001. [The diatoms of Pliocene and Anthropogen of the North Pacific (stratigraphy and paleoecology)]. Vladivostok: Dal'nauka, $217 \mathrm{p}$.

49. Razzhigaeva N.G., Ganzei L.A., Grebennikova T.A., Kopoteva T.A., Klimin M.A., Panichev A.M., Kudriavtseva E.P., Arslanov Kh.A., Maksimov F.E., Petrov A.Iu. 2019. [Chronicle of river floods in the foothills of the Sikhote-Alin for the last 2.2 thousands years]. Izvestiya RAN. Seriya Geograficheskaya $=$ Bulletin of the Russian academy of Science: Geographical Series, (2): 85-99. doi.org/10.31857/S258755662019285-99

50. Rein B., Sirocko F., Lückge A., Reinhardt L., Wolf A., Dullo W.-Ch. 2005. El Niňo variability off Peru during the last 20,000 years. Paleoceanography, 20: PA4003, 17 p. doi.org/10.1029/2004PA001099

51. Sakaguchi Y. 1983. Warm and cold stages in the past 7600 years in Japan and their global correlation. Bull. of the Department of Geography, Univ. of Tokyo, 15: 1-31.

52. Sheshukova-Poretskaia V.S. 1967. Neogenovye morskie vodorosli Sakhalina i Kamchatki [Neogene seaweed of Sakhalin and Kamchatka]. Leningrad: Izd-vo LGU [Leningrad State University press], 432 p.

53. Sheshukova-Poretskaia V.S. (ed.) 1974. Diatomovye vodorosli SSSR. Iskopaemye i sovremennye [The Diatoms of the USSR. Fossil and recent]. Vol. 1. Leningrad: Nauka Publ., $400 \mathrm{p}$.

54. Sitnikov I.G., Pokhil A.E., Tunegolovets V.P. 2001. [Typhoons]. In: Prirodnye opasnosti Rossii. Gidrometeorologicheskie opasnosti [Nature hazards of Russia. Hydrometeorological hazards]. Moscow: KRUK, vol. 5: 84-126.

55. Stebich M., Rehfeld K., Schlütz F., Tarasov P.E., Liu J. 2015. Holocene vegetation and climate dynamic of NE China based on the pollen record from Sihailongwan Maar Lake. Quaternary Science Reviews, 124: 275-289. doi.org/10.1016/j.quascirev.2015.09.005

56. Torf i produkty ego pererabotki. Metody opredeleniia zol'nosti [Peat and the products of its treatment. Test methods of ash content]: GOST 11306-83. 1995. Moscow: Izd-vo standartov [Moscow: Standards Publ. House], 7 p.

57. Tsoy I., Prushkovskaya I., Aksentov K., Astakhov A. 2015. Environmental changes in the Amur Bay (Japan/East Sea) in the past 150 years on the basis of diatoms and silicoflagellates. Ocean Science J., 50(2): 433-444. doi.org/10.1007/s12601-015-0039-8

58. Tunegolovets V.P. 1998. Tropicheskie tsiklony severo-zapadnoi chasti Tikhogo okeana: struktura, evoliutsiia, prognoz intensivnosti i peremeshcheniia statisticheskimi metodami [Tropical cyclones of the northwest Part of the Pacific Ocean: structure, evolution, prediction of intensity and shift with the statistical methods]: [dissertation abstract of Doctor of geographical sciences]. Vladivostok, $50 \mathrm{p}$.

59. Tunegolovets V.P. 2009. [Cyclogenesis intensity in the second half of the XX century]. Trudy DVNIGMI [Proceedings of the Far Eastern Regional Hydrometeorological Research Institute (FERHRI)], 151: 140-153.

60. Tunegolovets V.P. 2010. [Complex method of the typhoons shift and intensity prediction]. Trudy DVNIGMI, (1): 189-202

61. Wang L., Lu H., Liu J., Gu Z., Mingram J., Chu G., Li J., Rioual P., Negendank J.F.W., Han J., Liu T. 2008. Diatom-based inference of variation in the strength of Asian winter monsoon winds between 17,500 and 6000 calendar B.P. J. Geophysical Research, 113: D21101, 9 p. doi.org/10.1029/2008JD010145

62. Wanner H., Solomina O., Grosjean M., Ritz S.P., Jetel M. 2011. Structure and origin of Holocene cold events. Quaternary Science Reviews, 30: 3109-3123. doi.org/10.1016/j.quascirev.2008.06.013

63. Woodruff J.D., Donnelly J.P., Okusu A. 2009. Exploring typhoon variability over the mid-to-late Holocene: evidence of extreme coastal flooding from Kamikoshiki, Japan. Quaternary Science Reviews, 29: 1774-1785. doi.org/10.1016/j.quascirev.2009.02.005 